\title{
Balkon Pintar Kreatif Berkonsep Compulsory Education di Desa Koa, Kecamatan Mollo Barat, Kabupaten Timor Tengah Selatan (TTS), Provinsi Nusa Tenggara Timur (NTT)
}

\author{
Budi Kurniawan ${ }^{1 *}$, Ivo Basri $\mathbf{K}^{2}$, Elisabeth E. Fernandes ${ }^{3}$, Muffaridun Balangga ${ }^{4}$, \\ Salfian Ismail Dede ${ }^{5}$ iD \\ 1,2 Program Studi Pendidikan Guru Sekolah Dasar, Universitas Muhammadiyah Kupang, Indonesia \\ *Corresponding author: kurniawanbudi012@gmail.com
}

\begin{abstract}
Abstrak
Sumber daya manusia pada Desa Koa tergolong rendah dikarenakan rata-rata tingkat pendidikan di Desa Koa hanya sebatas di sekolah menengah pertama (SMP), rendahnya kesadaran pendidikan masyarakat di Desa Koa merupakan faktor utama penyebab lemahnya kualitas SDM. Tujuan pengabdian kepada masyarakat (PkM) ini adalah membangun balkon kreatif berkonsep compulsory education yang diharapkan dapat meningkatkan hard skill, soft skill, life skill serta memberdayakan masyarakat dalam hal pendidikan di Desa Koa, Kecamatan Mollo Barat, Kabupaten Timor Tengah Selatan (TTS), Provinsi Nusa Tenggara Timur (NTT). Pelaksanaan kegiatan berlangsung pada tanggal 4 Oktober 2021 di Desa Koa. Metode pelaksanaan yang digunakan dalam PkM dibagi menjadi 7 (tujuh) tahap diantaranya: 1) observasi dan wawancara, 2) pemetaan masalah, 3) pembangunan balkon, 4) pembuatan media pembelajaran, 5) mengadakan sosialisasi literasi media pembelajaran 6) sosialisasi pelatihan keterampilan hard skill dan soft skill, 7) sosialisasi pendidikan keterampilan hidup (life skill), 8) pelaksanaan PkM dengan melibatkan berbagai pihak diantaranya : Pihak Desa : Kepala Desa Koa, Masyarakat, Guru, Peserta Didik (siswa) SD dan Pihak Perguruan Tinggi: Dosen Program Studi Pendidikan Guru Sekolah Dasar (PGSD) Universitas Muhammadiyah Kupang dan Mahasiswa. Hasil analisis dengan survei menunjukkan bahwa peseta didik $90 \%$ sangat antusias dan memberikan respon yang sangat baik selama kegiatan berlangsung maupun setelah adanya balkon pintar kreatif berkonsep compulsory education dan luaran dari kegiatan ini adalah pemahaman masyarakat dan peserta didik tentang pemanfaatan balkon pintar kreatif untuk meningkatkan soft skill, hard skill, life skill yang harus dimiliki, dan pentingnya media pembelajaran dalam proses pembelajaran.
\end{abstract}

Kata Kunci: Balkon Pintar, Campulsory Education, Media Pembelajaran

\section{Abstract}

Human resources in Koa Village are low because the average The level of education in Koa Village is only limited to junior high school (SMP), The low awareness of public education in Koa Village is the main factor the cause of the weak quality of human resources. The purpose of this community service (PkM) is to build a creative balcony with the concept of compulsory education which is expected to improve hard skills, soft skills, life skills and empower the community in terms of education in Koa Village, West Mollo District, South Central Timor Regency (TTS), Province East Nusa Tenggara (NTT). The activity will take place on October 4, 2021 in Koa Village. The implementation method used in PkM is divided into 7 (seven) stages including: 1) observation and interviews, 2) problem mapping, 3) balcony construction, 4) learning media creation, 5) socializing learning media literacy 6) socialization of hard skills training skills and soft skills, 7) socialization of life skills education (life skills), 8) implementation of PkM by involving various parties including: Village Party: Koa Village Head, Community, Teachers, Elementary School Students (students) and Higher Education Parties: Program Lecturers Study of Elementary School Teacher Education (PGSD) University of Muhammadiyah Kupang and Students. The results of the analysis with the survey showed that $90 \%$ of students were very enthusiastic and gave a very good response during the activity and after the existence of the creative smart balcony with the concept of compulsory education and the output of this activity was the understanding of the community and students about the use of creative smart balcony to improve soft skills., hard skills, life skills that must be possessed, and the importance of learning media in the learning process.

Keywords: Smart Balcony, Campulsory Education, Learning Media

$\begin{array}{ll}\text { History: } & \\ \text { Received } & \text { : September 10, } 2021 \\ \text { Revised } & \text { : September 12, } 2021 \\ \text { Accepted } & \text { : November 03, 2021 } \\ \text { Published } & \text { : November } 25,2021\end{array}$




\section{PENDAHULUAN}

Desa Koa merupakan salah satu Desa yang berada di Kecamatan Mollo Barat, Kabupaten Timor Tengah Selatan (TTS) Provinsi Nusa Tenggara Timur (NTT) terletak dibawa kaki gunung dengan ketinggian $500 \mathrm{mdpl}$, luas wilayah Desa Mollo Barat berkisar 164,14 $\mathrm{km}^{2}$. Sedangkan luas wilayah Timur Tengah Selatan sekitar $3.3955 .56 \mathrm{~km}^{2}$ Kecamatan Mollo barat Beriklim tropis dengan suhu udara pada siang hari $17^{\circ} \mathrm{C}$ dan pada malam hari naik menjadi $23^{\circ} \mathrm{C}$. Kelembapan suhu udara di Kecamatan Mollo Barat yaitu 25-28\%. Curah hujan tertinggi terjadi pada bulan Desember-Maret, dan terendah terjadi pada bulan April, curah hujan rata-rata di Kecamatan Mollo Barat terjadi di setiap tahun di bulan yang sama dengan massa bulan kering sebanyak 6 bulan disetiap tahunnya. Desa Koa merupakan daerah perbukitan dan memiliki jenis tanah berbatuan, $\mathrm{Ph}$ tanah normal 6-8 kemungkinan untuk tersedianya berbagai unsur tanah yang seimbang. Penduduk Desa Koa di setiap tahunnya mengalami peningkatan dan juga sumber daya alamnya mencukupi, namun kualitas sumber daya manusia kurang (Danial et al., 2019; Hafifuddin, 2017). Jumlah penduduk di Desa Koa pada tahun 2021 yaitu 2.222 jiwa terdiri dari 1.022 laki-laki dan 1.222 perempuan. Jumlah kepala keluarga di Desa Koa 425 kk. Jumlah penduduk menurut umur yang ada di Desa Koa yang lebih mendominasi itu anak-anak ketimbang usia yang sudah lansia (Himawan et al., 2021; Ilmi, 2018). Tingkat pendidikan pada masyarakat di Desa Koa rata-rata SMP sederajat. Penduduk Desa Koa bermata pencarian petani, penambang pasir, berdagang, ternak, dan lain sebagainya (Lase, 2019).

Kondisi sosial masyarakat yang ada di Desa Koa sangat baik. Beberapa kondisi sosial masarakat yang berhubungan erat dengan etika dan budaya yakni menjunjung tinggi keserdehanaan, menjunjung tinggi norma-norma yang belaku, memiliki sifat kekeluargaan yang erat, menjunjung tinggi agama, menjunjung tinggi sikap gotong royong, bersikap sopan santun dan ramah tamah, serta selalu bermusyawarah (Andriani et al., 2021; Cartono et al., 2018; Siagian \& Rahmanita, 2020). Kondisi ekonomi masyarakat Desa Koa memanfaatkan pertanian, karena kehidupan masyarakat disana bergantungan pada sumber daya alam, seperti padi untuk memenuhi kehidupan sehari-harinya (M Yahya, 2018; Silooy, 2017). Begitu juga dengan tanaman-tanaman lain seperti sayur-mayur untuk memenuhi kebutuhan hidup. Lingkungan di Desa Koa, kondisi jalannya sebagian rusak parah Ketika musim hujan dan tidak bisa di lalui mobil karena jalannya berlumpur dan licin. Akses jalan di Desa tersebut bisa menggunakan sepeda motor akan tetapi harus berhati-hati karena jalannya di penuhi bebatuan. Rumah-rumah di Desa Koa juga sangat sederhana seperti gubuk yang dindingnya terbuat dari bebak dan atapnya terbuat dari daun lontar. Disana juga tidak ada TV atau alat Elektronik apapun singkatnya tidak ada sinyal, akan tetapi keindahan di Desa Koa yang sangat mempesona serta udaranya yang begitu sejuk mampu mendamaikan hati dan pikiran. Namun, sulitnya akses jalan yang terputus menyebabkan harus melewati sungai/kali, disajikan pada Gambar 1.

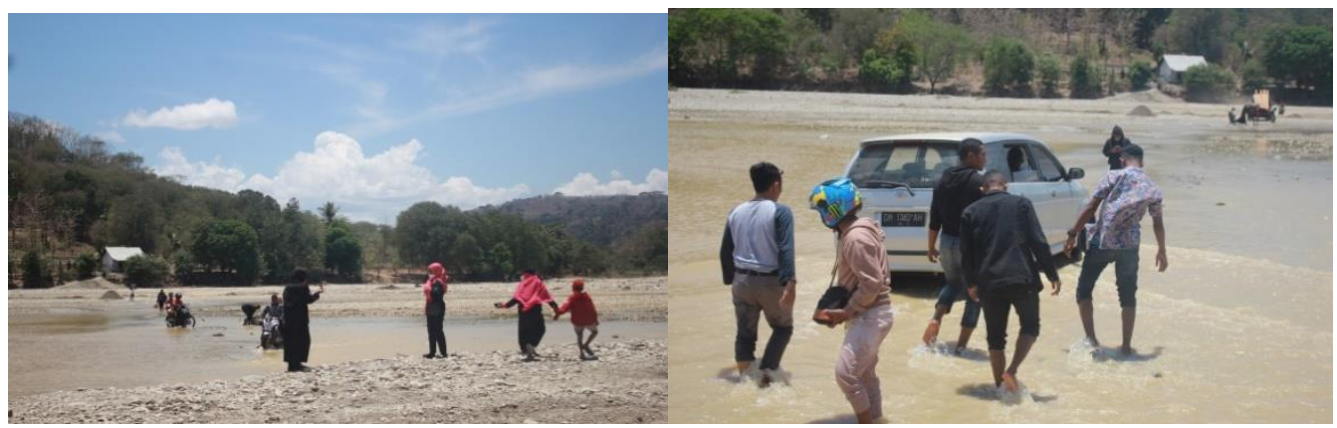

Gambar 1. Akses Jalan yang Terputus 
Desa Koa adalah salah satu Desa penghasil padi, kacang, ubi, dan jagung, oleh sebab itu tanaman padi adalah tanaman unggul di Desa Koa dengan luas perkebunan 2000.000 hektar. Pertanian andalan masyarakat di Desa Koa dan sampai saat ini salah satu Desa penghasil padi, kacang, ubi, dan jagung tetapi seiring berkembang pesatnya tanaman perkebunan maka lahan untuk menanam jagung mulai berkurang dan keluhan para petani saat ini adalah curah hujan yang turun terus menerus mengakibatkan jagung mengalami kerusakan (Purba et al., 2020; Purwaningsih, 2008). Peternakan salah satu potensi unggulan di Desa Koa yang masih terus di kembangkan dengan pengambilan bibit ternak yang diambil dari Takari, dengan potensi alam yang sangat mendukung wilayah Mollo Barat Desa Koa sangat cocok untuk pengembangan perternakan (Sumanto \& Takandjandji, 2014). Sumber daya manusia pada Desa Koa tergolong rendah dikarenakan rata rata tingkat pendidikan di Desa Koa hanya sebatas di sekolah menengah pertama (SMP), rendahnya kesadaran pendidikan masyarakat di Desa Koa merupakan faktor utama penyebab lemahnya kualitas SDM (Leiwakabessy \& Lahallo, 2018; Wassahua, 2016). Oleh karena itu, di Desa Koa membutuhkan suplemen pendidikan secara komprehensif dengan memaksimalkan halaman kosong di daerah sekitar Desa Koa untuk membangun Balkon Pintar Kreatif yang nantinya akan di isi dengan media-media pembelajaran yang bervariasi (Pinahayu \& Marfu'ah, 2020; Tafonao, 2018). Hal ini di harapkan mampu meningkatkan motivasi belajar anak-anak yang ada di Desa Koa.

\section{METODE}

Metode pendekatan yang ditawarkan untuk menyelesaikan persoalan peserta didik adalah : Waktu dan Tempat. Waktu pelaksanaan pengabdian ini adalah 2 hari terhitung dari tanggal 03 Oktober s.d 04 Oktober 2021. Pengabdian ini dilaksanakan di Desa Koa, Kecamatan Mollo Barat, Kabupaten Timor Tengah Selatan (TTS), Provinsi Nusa Tenggara Timur (NTT); Observasi Lapangan. Observasi lapangan dilakukan dengan melakukan survei langsung maupun diskusi dengan Kepala Desa dan masyarakat untuk mengetahui permasalahan yang dihadapi oleh peserta didik di lingkungan sekolah; Kerjasama Kemitraan Sangat dibutuhkan kerjasama kemitraan antara Kepala Desa Koa, Mayarakat, dan Perguruan Tinggi (PT) dalam hal ini pada Program Studi Pendidikan Guru Sekolah Dasar (PGSD) dan Program Studi Pendidikan Biologi, Universitas Muhammadiyah Kupang untuk mendukung kegiatan balkon pintar kreatif berbasis compulsory education di Desa Koa, Kecamatan Mollo Barat, Kabupaten TTS, Provinsi NTT.

Pembangunan balkon. Balkon dibangun dengan tujuan sebagai wadah bagi masyarakat untuk menciptakan ekosistem belajar yang nyaman; Sosialisasi/penyuluhan. Perlu adanya sosialisasi terhadap peserta didik dan masyarakat sekitar mengenai pentingnya literasi media pembelajaran, sehingga peserta didik dan masyarakat paham dan bersedia bekerja sama dan menerima metode-metode yang akan disampaikan (Hanika et al., 2020); Pelaksanaan sosialisai pelatihan keterampilan hard skill dan soft skill (Islami \& Fitria, 2019). Menjelaskan kepada peserta didik kemampuan-kemampuan yang harus dimiliki sejak usia dini sehingga peserta didik, sehingga peserta didik memiliki kesadaran, ketertarikan dan mencoba untuk memiliki kemampuan-kemampuan dasar yang sangat bermanfaat bagi diri sendiri dan orang lain (Rahmawati et al., 2019); Pelaksananaa sosialisasi keterampilan hidup (life skill). Sosialisasi keterampilan hidup dilaksanakan untuk memberikan wawasan kepada masyarakat khususnya peserta didik (Purbaya, 2021; Wijaya et al., 2020). Adapun kerangka pemikiran kegiatan PkM disajikan dalam bentuk flowchart pada Gambar 2. 


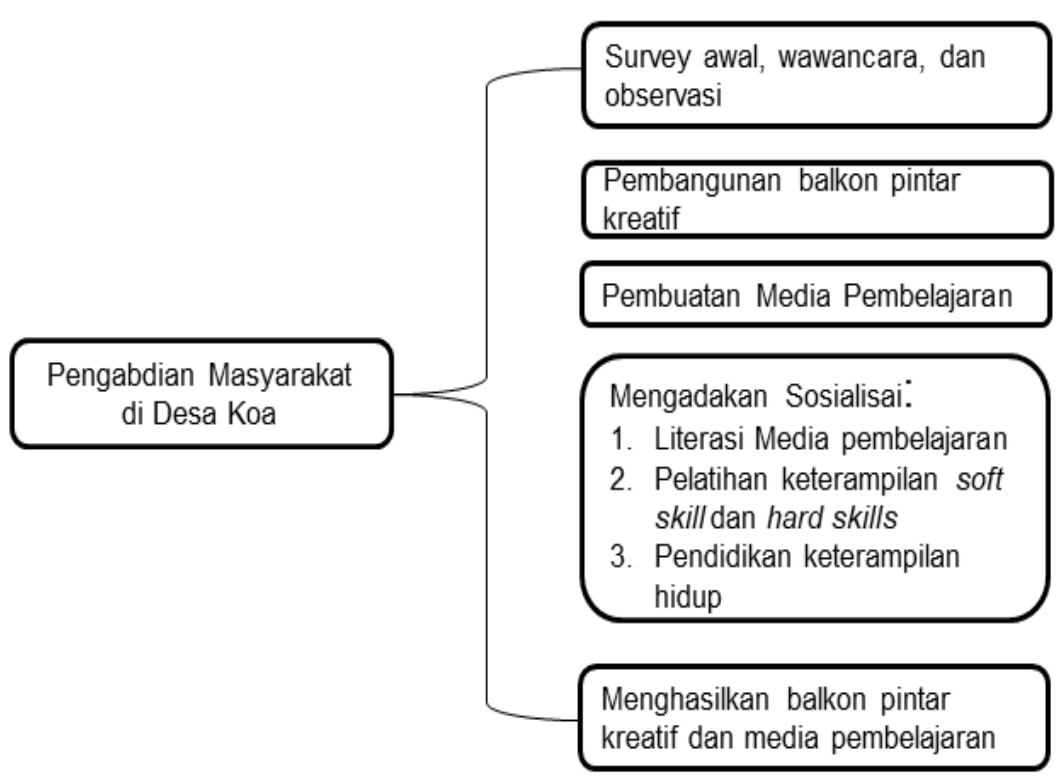

Gambar 2. Kerangka Pemikiran.

\section{HASIL DAN PEMBAHASAN}

\section{Hasil}

Kegiatan pengabdian kepada masyarakat $(\mathrm{PkM})$ dengan tema Balkon Pintar Kreatif Berbasis Compilsory Education, Kecamatan Mollo Barat, Kabupaten TTS, Provinsi NTT diawali dengan sambutan dari Kepala Desa Koa, Bapak Yustus Bani. Selanjutnya Tim Pelaksana kegiatan PkM mengucapkan terima kasih atas sambutan dan diberikannya izin melaksanakan pengabdian di Desa Koa. Dalam pelaksanaan kegiatan pelatihan ini strategi yang digunakan adalah membangun balkon pintar kreatif dan mengadakan sosialisasi. Dimulai dari melakukan survei awal sampai ketahap sosaialisasi. Langkah-langkah pelaksanaannya adalah melakukan survei awal, wawancara dengan Kepala Desa Koa, Bapak Yustus Bani. Disajikan pada Gambar 3.

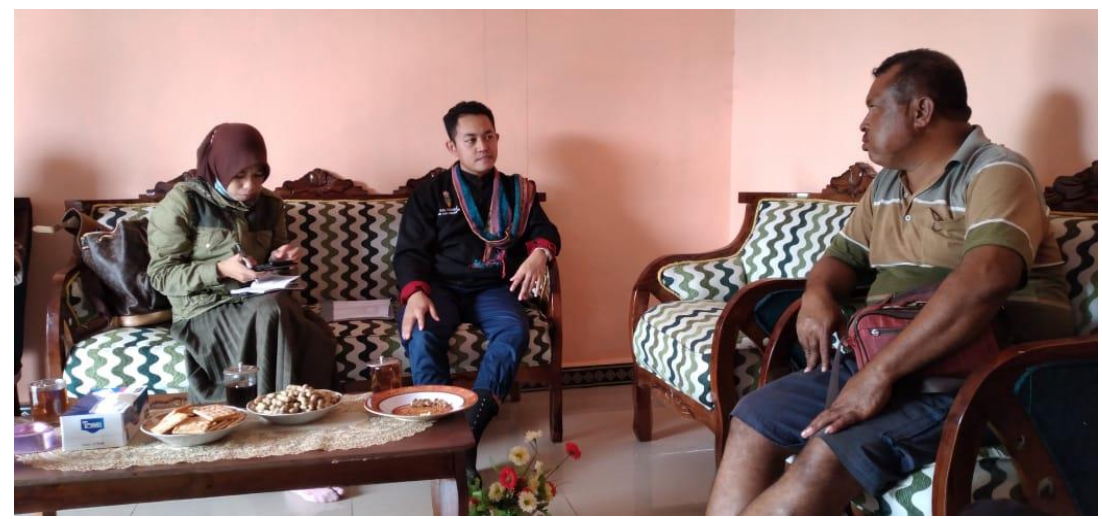

Gambar 3. Wawancara dengan Bapak Kepala Desa Koa

Pembangunan balkon pintar kreatif. Merancang balkon pintar kreatif dengan menentukan yang menjadi kebutuhan untuk mendukung kegiatan peserta didik, dengan berdasarkan informasi, seleksi konsep, evaluasi, menentukan spesifikasi alat dan bahan yang digunakan, serta analisis biaya operasional, yang disajikan pada Gambar 4. 


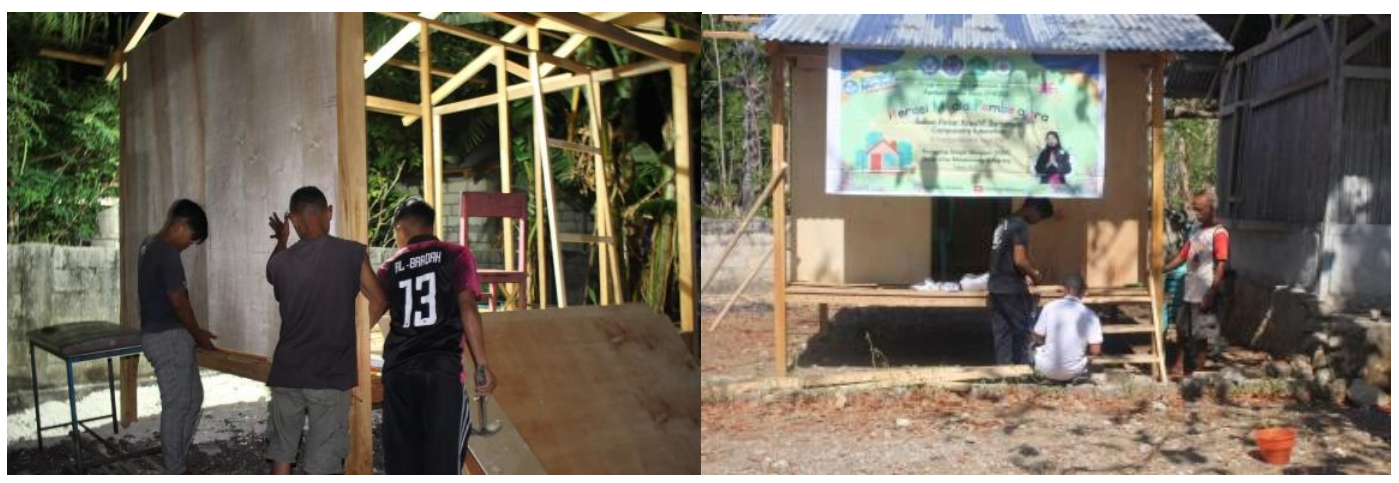

Gambar 4. Pembangunan Balkon Pintar Kreatif

Pembuatan media pembelajaran. Pembuatan media pembelajaran, dilaksanakan di sekretariat Komunitas Belajar Mengajar (KBM) Universitas Muhammadiyah Kupang, disajikan pada Gambar 5. Sosialisasi pelatihan media pembelajaran. Mengajarkan kepada peserta didik, mengenai pentingnya media pembelajaran serta menjelaskan cara penggunaan media pembelajaran yang tersedia, disajikan pada Gambar 6.

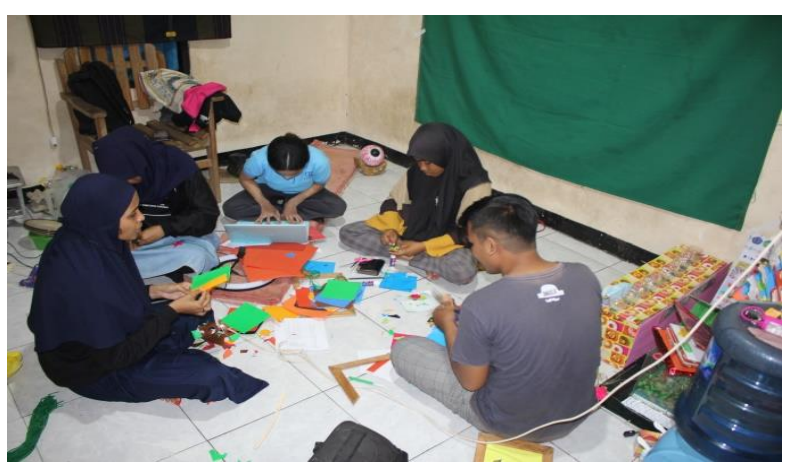

Gambar 5. Pembuatan Media Pembelajaran

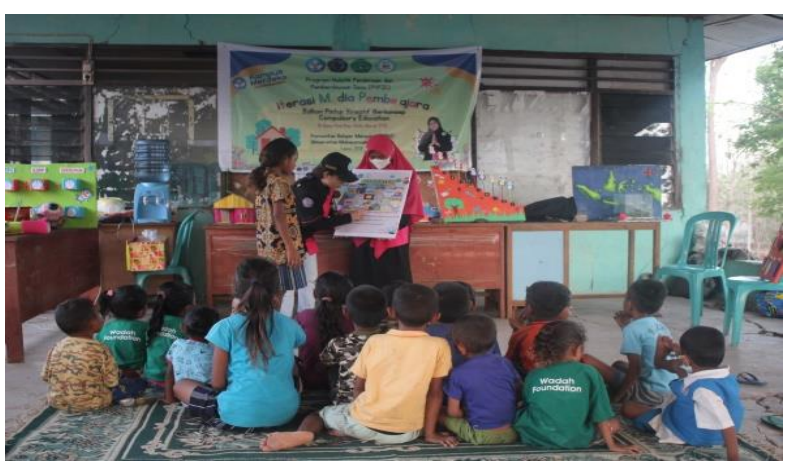

Gambar 6. Sosialisasi Literasi Media Pembelajaran

Sosialisasi Pelatihan keterampilan hard skills dan soft skills. Memberikan wawasan kepada peserta didik mengenai pentingnya hard skills dan soft skills dasar yang harus dimiliki sejak usia dini seperti mampu menguasai Information and Communication Technology (ICT) dan lain sebagainya, disajikan pada Gambar 7.Sosialisasi pendidikan keterampilan hidup. Menjelaskan serta memberikan beberapa contoh yang mampu membuat peserta didik paham mengenai pentingya keterampilan dalam kehidupan (life skill), disajikan pada Gambar 8.

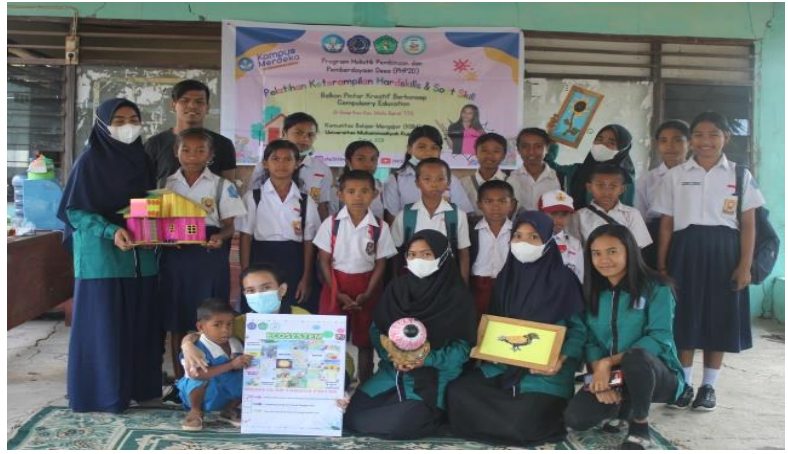

Gambar 7. Sosialisasi Pelatihan Keterampilan (Hard Skill dan Soft Skill)

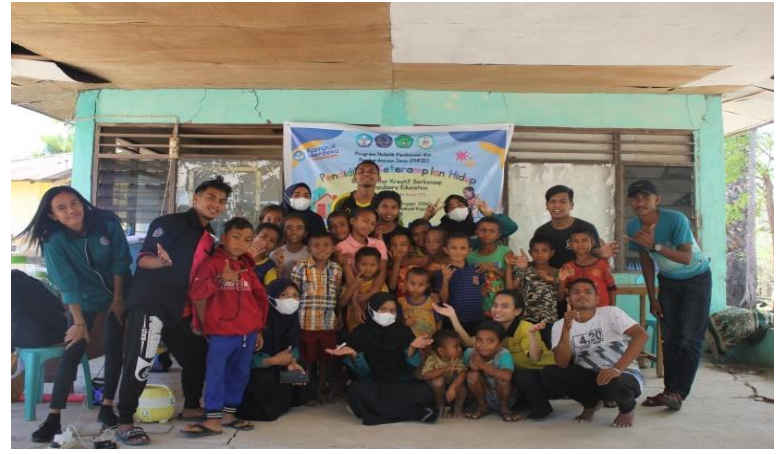

Gambar 8. Sosialisasi Pendidikan Keterampilan Hidup (Life Skill) 
Menghasilkan balkon pintar kreatif dan media pembelajaran. Balkon pintar kreatif sebagai wadah penyimpanan media pembelajaran. Media-media pembelajaran yang dibuat bertujuan untuk membantu peserta didik dalam proses pembelajaran, disajikan pada Gambar 9.

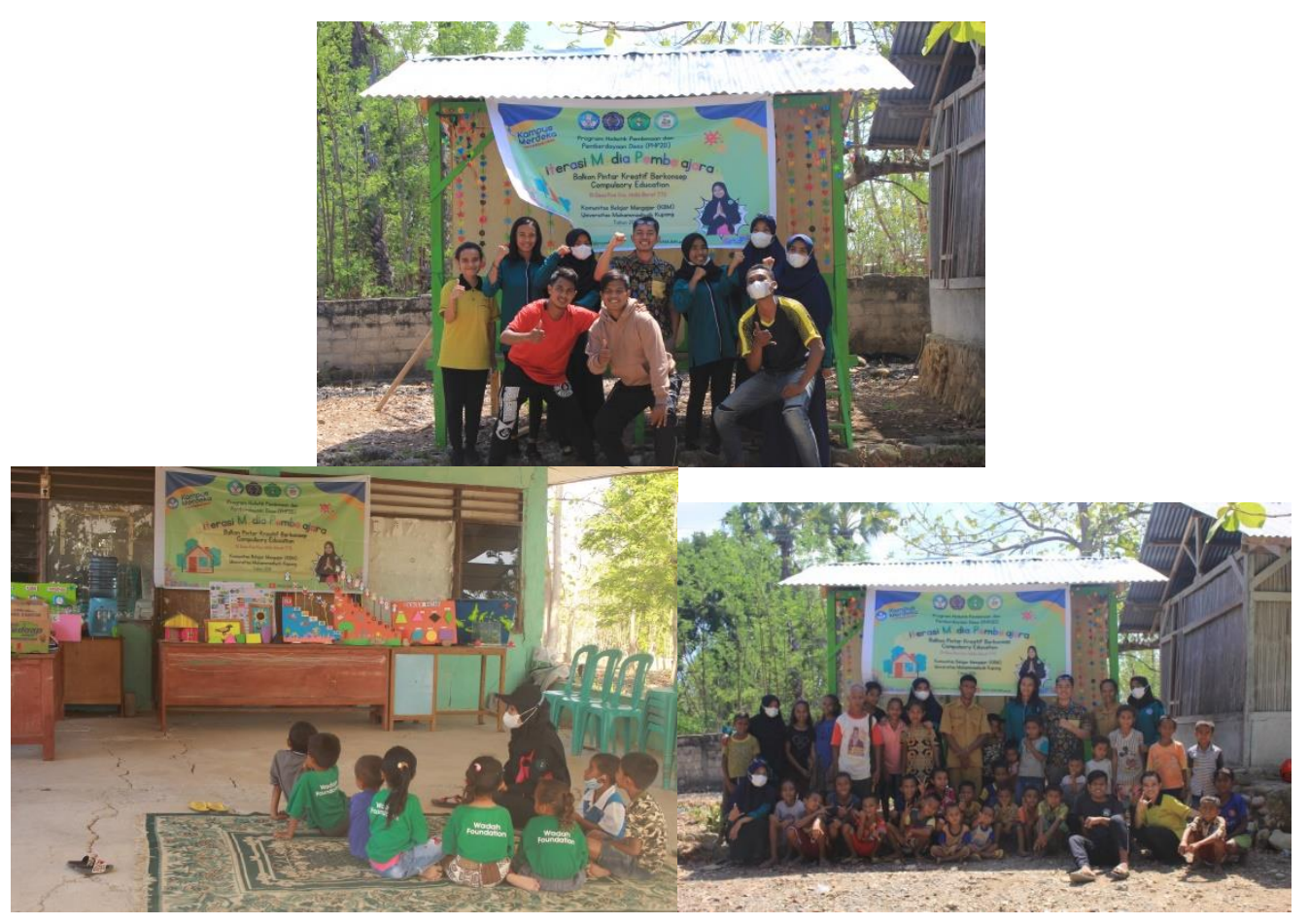

Gambar 9. Balkon dan Media Pembelajaran yang dihasilkan

\section{Pembahasan}

Perkembangan teknologi yang semakin canggih menjadi sarana penting untuk mencapai tujuan pendidikan yang lebih efektif dan efesien. Namun, di balik itu menjadi tuntutan besar bagi para dosen/guru untuk mengembangkan kemampuan dalam menguasai teknologi dan media pembelajaran. Peranan media pembelajaran dalam proses belajar dan mengajar sangat penting dilaksanakan oleh para pendidik saat ini, karena peranan media pembelajaran dapat digunakan untuk menyalurkan pesan pengirim kepada penerima dan melalui media pembelajaran juga dapat membantu peserta didik untuk menjelaskan sesuatu yang disampaikan oleh pendidik. Berdasarkan hasil analisis kebutuhan masyarakat di Desa Koa, banyak hal yang ditemukan, anatara lain : 1) kurangnya sarana dan prasarana di sekolah dan 2) tidak menggunakan media pembelajaran dalam proses pembelajaran sehingga masih sangat monoton pada buku. Oleh karena itu, dibangunnya balkon pintar kreatif, media-media pembelajaran, serta dengan melakukan sosialisasi tentang literasi media pembelajaran, keterampilan (hard skill dan soft skill), serta pendidikan keterampilan hidup (life skill). Kegiatan tersebut memberikan manfaat bagi peserta didik maupun masyarakat umum yang berada di Desa Koa. Hasil analisis dengan survei menunjukkan bahwa peseta didik 90\% sangat antusias dan memberikan respon yang sangat baik selama kegiatan berlangsung maupun setelah adanya balkon pintar kreatif berkonsep compulsory education.

Dalam pelaksanaan pengabdian kepada masyarakat (PkM), balkon pintar kreatif berkonsep compulsory education, peserta didik diajarkan cara mengaplikasikan media-media pembelajaran yang sudah tersedia. Hard skill merupakan salah satu jenis pengetahuan yang mudah didokumentasikan dan dibentuk, mudah diartikulasikan, dan biasanya merupakan pengetahuan yang melekat pada sekolah (Asbari, Wijayanti, et al., 2020; Goestjahjanti et al., 2020; Yanthy et al., 2020). Selain itu, hard skill dapat dibuat, ditulis dan ditransfer di antara 
unit kegiatan sekolah (Asbari \& Novitasari, 2020). Transfer hard skill di antara guru lebih mudah didorong oleh mekanisme dan budaya sekolah yang kondusif. Sementara itu, dalam proses sosialisai literasi media pembelajaran, pelatihan keterampilan (hard skill dan soft skill), serta sosialisasi pendidikan keterampilan hidup (life skill), mahasiswa menjelaskan beberapa keterampilan (skills) yang harus dimiliki oleh peserta didik sejak usia dini. Knowledge diklasifikasikan menjadi dua jenis meliputi: soft skill dan hard skill (Polanyi, 1966). Definisi soft skill merupakan pengetahuan yang masih berada dalam benak manusia dan bersifat sangat personal (Asbari, Purwanto, et al., 2020), sulit dirumuskan dan dibagi secara natural sehingga dalam transformasinya membutuhkan interaksi personal. Soft skill ini berada dan berakar di dalam tindakan maupun pengalaman seseorang, termasuk idealisme, nilai-nilai, maupun emosionalnya. Hard skills dan soft skills berpengaruh positif dan signifikan terhadap kemampuan inovasi guru, baik secara langsung maupun tidak langsung melalui mediasi organizational learning menjelaskan pentingnya media pembelajaran dalam proses pembelajaran, serta cara menerapkan keterampilan-keterampilan (skills) dalam kehidupan sehari-hari. Pengembangan keterampilan hidup dan karir pada setiap individu tentunya bukan menjadi tanggung jawab pihak sekolah saja, namun juga menjadi tanggung jawab setiap komponen yang merupakan Tri Pusat Pendidikan yaitu keluarga, sekolah dan masyarakat. Pengembangan keterampilan hidup dan karir sudah harus dilakukan ketika individu masih berada di sekolah dasar (SD), terdapat beberapa alasan yang melandasi hal tersebut (Magdalena et al., 2020; Nurhasanah, 2016).

\section{SIMPULAN DAN SARAN}

Kesimpulan yang di dapat dari kegiatan Pembinaan dan Pemberdayaan Desa (PHP2D) yang dilaksanakan di Desa Koa, Kecamatan Mollo Barat, Kabupaten Timor Tengah Selatan, NTT, diantaranya: 1) mendirikan balkon pintar kreatif kepada masyarakat sehingga mempermudah masyarakat untuk menciptakan ekosistem belajar yang baik dan nyaman, 2) masyarakat mendapatkan media-media pembelajaran yang mampu membantu dalam proses belajar mengajar, dan 3) hasil analisis dengan survei menunjukkan bahwa peseta didik 90\% sangat antusias dan memberikan respon yang sangat baik selama kegiatan berlangsung maupun setelah adanya balkon pintar kreatif berkonsep compulsory education dan luaran dari kegiatan ini adalah pemahaman masyarakat dan peserta didik tentang pemanfaatan balkon pintar kreatif untuk meningkatkan soft skill, hard skill, life skill yang harus dimiliki, dan pentingnya media pembelajaran dalam proses pembelajaran.

\section{DAFTAR RUJUKAN}

Andriani, S. D., Susilowati, D., \& Sudjoni, M. N. (2021). Analisis Partisipasi Masyarakat pada Program PHP2D Himagri Unisma di Kelurahan Merjosari Kota Malang. Jurnal Sosial Ekonomi Pertanian Dan Agribisnis, 9(3). http://www.riset.unisma.ac.id/index.php/SEAGRI/article/view/12856.

Asbari, M., \& Novitasari, D. (2020). Pengaruh Aktivitas Berbagi Pengetahuan dan Mediasi Budaya terhadap Kemampuan Inovasi Guru. JMSP (Jurnal Manajemen Dan Supervisi Pendidikan), 5(1), 50-60. http://journal2.um.ac.id/index.php/jmsp/article/view/15253.

Asbari, M., Purwanto, A., Ong, F., Mustikasiwi, A., Maesaroh, S., Mustofa, M., ... \&, \& Andriyani, Y. (2020). Impact of Hard Skills, Soft Skills and Organizational Culture: Lecturer Innovation Competencies As Mediating. EduPsyCouns: Journal of Education, Psychology and Counseling, 2(1), 101-121. https://ummaspul.ejournal.id/Edupsycouns/article/view/419.

Asbari, M., Wijayanti, L. M., Hyun, C. C., Imelda, D., \& Purwanto, A. (2020). Hard Skills 
atau Soft Skills: Manakah yang lebih penting bagi Inovasi Guru. Edumaspul: Jurnal Pendidikan, 4(1), 1-20. https://ummaspul.e-journal.id/maspuljr/article/view/333.

Cartono, C., Hizqiyah, I. Y. N., \& Aryanti, F. (2018). Pengembangan Softskill Mahasiswa Calon Guru melalui Pemberdayaan Unit Kegiatan Mahasiswa di Universitas Pasundan. Jurnal Komunikasi Pendidikan, 2(1), 69-76. http://journal.univetbantara.ac.id/index.php/komdik/article/view/66.

Danial, A., Karwati, L., \& Hamdan, A. (2019). Model Pendidikan Keterampilan Terintegrasi dengan Nilai-Nilai Budaya Lokal dalam Memanfaatkan Sumber Potensi Alam. Jurnal Eksistensi Pendidikan Luar Sekolah (E-Plus), 4(1). http://jurnal.untirta.ac.id/index.php/E-Plus/article/view/6272.

Goestjahjanti, F. S., Purwanto, A., Asbari, M., Wijayanti, L. M., Hyun, C. C., Agistiawati, E., \& Dewi, W. R. (2020). Pengaruh Organizational Learning Terhadap Peningkatan Hard Skills, Soft Skills Dan Inovasi Guru. EduPsyCouns: Journal of Education, Psychology and Counseling, 2(1), 202-226. https://ummaspul.ejournal.id/Edupsycouns/article/view/436.

Hafifuddin, H. (2017). Disentralisasi Pendidikan Dalam Meningkatkan Kualitas Sumber Daya Manusia Kota Lhokseumawe. Itqan: Jurnal Ilmu-Ilmu Kependidikan, 8(2), 169186. https://ejurnal.iainlhokseumawe.ac.id/index.php/itqan/article/view/110.

Hanika, I., Putri, M. I., \& Witjaksono, A. A. (2020). Sosialisasi Literasi Media Digital di Jakarta (Studi Eksperimen Penggunaan Youtube terhadap Siswa Sekolah Dasar Di Jakarta). Jurnal Komunikasi Dan Kajian Media, 4(2), 153-172. https://jurnal.untidar.ac.id/index.php/komunikasi/article/view/3324.

Himawan, R., Kelana, R. A., Afrilia, T., \& Sari, A. (2021). Pembentukan UMKM melalui Program Hibah PHP2D Kemdikbud sebagai Recovery Dampak Covid-19 di Desa Gilangharjo. Jurnal Pengabdian Dharma Laksana, 3(2), 147-153. http://openjournal.unpam.ac.id/index.php/jpdl/article/view/8839.

Ilmi, N. S. A. (2018). Potret kehidupan pengemis anak di Kecamatan Sooko Kabupaten Mojokerto: dalam tinjauan teori interaksi simbolik. UIN Sunan Ampel Surabaya.

Islami, N. N., \& Fitria, F. L. (2019). Pelatihan Strategi Digital Marketing untuk Meningkatkan Kemampuan Soft skill dan Hard skill Bidang Keahlian Pemasaran Pada Siswa Jurusan Pemasaran SMK Nuris Hidayat Desa Curahnongko, Kec. Tempurejo Kab. Jember. Jurnal Pendidikan Ekonomi: Jurnal Ilmiah Ilmu Pendidikan, Ilmu Ekonomi Dan Ilmu Sosial, 13(2), 34-40. https://jurnal.unej.ac.id/index.php/JPE/article/view/13854.

Lase, D. (2019). Pendidikan di Era Revolusi Industri 4.0. SUNDERMANN: Jurnal Ilmiah Teologi, Pendidikan, Sains, Humaniora Dan Kebudayaan, 12(2), 28-43. http://jurnal.sttsundermann.ac.id/index.php/sundermann/article/view/18.

Leiwakabessy, P., \& Lahallo, F. F. . (2018). Pembiayaan Usaha Mikro Kecil dan Menengah (UMKM) sebagai Solusi dalam Meningkatkan Produktivitas Usaha pada UMKM Kabupaten Sorong. Journal of Dedication to Papua Community (J-DEPACE), 1(1), 11-21. http://www.jurnal.lpmiunvic.ac.id/index.php/jpkm/article/view/2.

M Yahya, A. (2018). Analisis Kehidupan Ekonomi Petani Mitra Ptpn Xiv Pabrik Gula Takalar. Universitas Negeri Makassar.

Magdalena, I., Rosnaningsih, A., Akbar, M., \& Situmorang, R. (2020). Evaluasi Program Gerakan Literasi Sekolah Di Sekolah Dasar Wilayah Kota Dan Kabupaten Tangerang. Pendas: Jurnal Ilmiah Pendidikan Dasar, 4(2), 230-248. http://www.journal.unpas.ac.id/index.php/pendas/article/view/1768.

Nurhasanah, A. (2016). Penggunaan metode simulasi dalam pembelajaran Keterampilan Literasi Informasi IPS bagi Mahasiswa PGSD. JPsd (Jurnal Pendidikan Sekolah Dasar), 2(1), 87-95. http://jurnal.untirta.ac.id/index.php/jpsd/article/view/670. 
Pinahayu, E. A. R., \& Marfu'ah, I. (2020). Sosialisasi Media Pembelajaran dan Program Statistika di SD Negeri Setu 01 Cipayung. Jurnal PkM (Pengabdian Kepada Masyarakat), 3(4),

318-325. https://scholar.archive.org/work/hxkkwdp4dbffdke6fk5byzxmku/access/wayback/http s://journal.lppmunindra.ac.id/index.php/pkm/article/download/5609/3670.

Polanyi, M. (1966). The logic of tacit inference. Philosophy, 41(155), 1-18. https://www.cambridge.org/core/journals/philosophy/article/logic-of-tacitinference/067C495A943E876DEE838320A1B5D522.

Purba, D. W., Thohiron, M., Surjaningsih, D. R., Sagala, D., Ramdhini, R. N., Gandasari, D., ... \&, \& Manullang, S. O. (2020). Pengantar ilmu pertanian. Yayasan Kita Menulis.

Purbaya, D. A. (2021). Pelaksanaan Pemberdayaan Masyarakat melalui Program Keterampilan Hidup dan Wirausaha di PKBM Luthfillah Kelurahan Pahandut Kota Palangka Raya. Journal Ilmu Sosial, Politik Dan Pemerintahan, 10(1). https://ejournal.upr.ac.id/index.php/JISPAR/article/view/2288.

Purwaningsih, Y. (2008). Ketahanan pangan: situasi, permasalahan, kebijakan, dan pemberdayaan masyarakat. Jurnal Ekonomi Pembangunan: Kajian Masalah Ekonomi Dan Pembangunan, 9(1), 1-27. https://journals.ums.ac.id/index.php/JEP/article/view/1028.

Rahmawati, N. S., Bungsu, T. K., Islamiah, I. D., \& Setiawan, W. (2019). Analisis minat belajar siswa ma al-mubarok melalui pendekatan saintifik berbantuan aplikasi geogebra pada materi statistika dasar. Journal On Education, 1(3), 386-395. http://www.jonedu.org/index.php/joe/article/view/180.

Siagian, A., \& Rahmanita, F. (2020). Potret Budaya Hukum Masyarakat Sederhana Indonesia dalam Merawat Kebhinnekaan. Jurnal Ilmiah Humanika, 3(1), 43-51. http://humanika.penapersada.com/index.php/humanika/article/view/41.

Silooy, M. (2017). Analisis Faktor-Faktor Yang Mempengaruhi Tingkat Kemiskinan Absolut Masyarakat Pesisir (Nelayan) Di Desa Seilale Kecamatan Nusaniwe. Cita Ekonomika, 11(1), 79-84. https://ojs3.unpatti.ac.id/index.php/citaekonomika/article/view/2634.

Sumanto, S. E., \& Takandjandji, M. (2014). Identifikasi pemanfaatan hasil hutan oleh masyarakat: Upaya konservasi sumber daya genetik dan sosial budaya. Buletin Plasma Nutfah, 20(1), 27-40. http://ejurnal.litbang.pertanian.go.id/index.php/bpn/article/view/5185.

Tafonao, T. (2018). Peranan media pembelajaran dalam meningkatkan minat belajar mahasiswa. Jurnal Komunikasi Pendidikan, 2(2), 103-114. http://journal.univetbantara.ac.id/index.php/komdik/article/view/113.

Wassahua, S. (2016). Analisis faktor-faktor penyebab anak putus sekolah di kampung wara negeri hative kecil kota ambon. Al-Iltizam: Jurnal Pendidikan Agama Islam, 1(2), 204-224. https://mail.iainambon.ac.id/ojs/ojs-2/index.php/ALT/article/view/199.

Wijaya, I. K. W. B., Darmayanti, N. W. S., \& Muliani, N. M. (2020). Pengembangan Keterampilan Hidup dan Karir Siswa Sekolah Dasar dalam Rangka Peningkatan Mutu Lulusan Sekolah Dasar. Jurnal Penjaminan Mutu, 6(2), 171-181. http://ejournal.ihdn.ac.id/index.php/JPM/article/view/1384.

Yanthy, E., Sudiyono, R. N., Waruwu, H., Agistiawati, E., \& Purwanto, A. (2020). Pengaruh Soft Skills Dan Hard Skill Terhadap Inovasi Guru Sekolah Islam. Refleksi Edukatika: Jurnal Ilmiah Kependidikan, 10(2), 199-215. https://jurnal.umk.ac.id/index.php/RE/article/view/4555. 